\title{
Grammaticalization in Germanic languages
}

\author{
Martin Hilpert
}

\section{Genetic and structural characteristics}

The Germanic languages represent a branch of the Indo-European language family that is traditionally traced back to a common ancestor, Proto-Germanic, which was spoken around $500 \mathrm{BC}$ in the southern Baltic region (Henriksen and van der Auwera 1994). Three subbranches, East-, West-, and North-Germanic, are recognized; of these, only the latter two survive in currently spoken languages. The now-extinct East-Germanic branch included Burgundian, Gothic, and Vandalic. The North-Germanic branch is represented by Danish, Faroese, Icelandic, Norwegian, and Swedish. West-Germanic, which is less clearly identifiable as a single branch than North-Germanic, has given rise to Afrikaans, Dutch, English, Frisian, German, and Yiddish. The living Germanic languages have an extremely wide geographical distribution beyond the Proto-Germanic territory; besides colonial varieties (Afrikaans) and emigrant varieties (Texas German), many non-native varieties (Indian English) and creoles (Tok Pisin) are based on Germanic languages.

Structurally, the Germanic languages are characterized by a pervasive loss of Proto-IndoEuropean inflectional categories. In comparison, English and Afrikaans exhibit the highest degree of analyticity, whereas German and Icelandic retain categories such as case, gender, and number on nouns and adjectives. For instance, Icelandic maintains an inflectional distinction between indicative and subjunctive across present and past forms of verbs (Thràinsson 1994).

Several morphological and syntactic commonalities are worth noting. The Germanic languages share a morphological distinction between present and preterite in the verbal domain. Here, an older system of strong verbs, which form the past tense through ablaut (sing - sang), contrasts with a newer system of weak verbs that have a past tense suffix containing an alveolar or dental stop (play - played). Generally, suffixation is much more common than prefixation. All Germanic languages exhibit derivational suffixes that allow the formation of new words from nominal, verbal, and adjectival stems. Some of these, such as English -ly, -ship, or -some go back to a common Proto-Germanic origin.

A syntactic commonality is the so-called V2 (verb-second) order. As a default, the Germanic languages exhibit SVO word order in declarative main clauses (German: Ich trinke Kaffee - I drink coffee). However, if a constituent is fronted for the purpose of topicalization, the subject will follow the verb rather than precede it (Kaffee trinke ich nie-Coffee I never drink). As can be seen from the last gloss, English deviates from the other Germanic languages in this respect. However, V2 used to exist even in English and is retained in a few stylistically marked constructions (Into the room walked Noam Chomsky). In alignment with the characteristic of SVO order, the Germanic languages exhibit prepositions rather than postpositions. Also, they share a large inventory of clause-initial adverbial subordinators (Kortmann 1997). Another common syntactic feature of the Germanic languages is the expression of yes-no questions by means of word order rearrangements, specifically the fronting of the verb. Again, English assumes a special role, since the pattern of $d o$-support (Culicover 2008) complicates the picture. 


\section{Historical documentation and research methodology}

The history of the Germanic languages is preserved rather well; at least for all national languages, substantial written materials from early stages onwards are available. The main research methodology is thus the philological study of texts from different historical periods. By comparing the usage patterns of a linguistic item across several periods, it can be determined when and how that item underwent qualitative changes in form and meaning. For instance, a comparison of this kind can determine when approximately during its grammaticalization English can lost its infinitive form or ceased to take direct objects.

In recent years, many historical materials have been made available in electronic format, thus affording corpus-based investigations into grammaticalization phenomena (Mair, this volume). This development has enabled researchers to establish an additional focus on quantitative changes. Accounts of grammaticalization phenomena now commonly report frequency developments. A grammaticalizing form may become more frequent, either in absolute terms or relative to its lexical source. To take another example from English, aspectual keep $V$-ing has increased both in absolute and in relative frequency over the past century. Alternatively, there may be changes in relative frequency, such as one variant form of a construction or one meaning of a polysemous item gradually ousting its competitors. By tracking frequency changes over time, corpus-based studies can provide fine-grained accounts, especially in scenarios of incipient or incomplete grammaticalization. Their main potential, however, lies in the empirical assessment of theoretical claims about grammaticalization. If hypotheses are operationalized in terms of corpus frequencies, then even gradual differences can help researchers to decide between two rivalling accounts of the same phenomenon.

Another important research strategy is the synchronic comparison of grammaticalized forms across the Germanic languages (cf. De Mulder and Lamiroy, this volume). In many grammatical domains, structurally analogous forms are used across different languages. Examples include $w h$-clefts, the perfect with have, or verb-initial conditional clauses (Had I known this, I wouldn't have come). These may differ cross-linguistically in their relative degree of grammaticalization, so that comparisons of this kind can yield insights into different developmental stages. They can also show how the same general grammaticalization path can give rise to quite different language-specific developments. To summarize, the rich data from the Germanic languages offers a fine level of detail that is useful both for the exploration of grammaticalization phenomena in Germanic and for the examination of hypotheses about grammaticalization in general.

\section{Language contact}

The languages of Europe exhibit many structural affinities that reflect deep-seated patterns of mutual contact and exchange (Heine and Kuteva 2006). Some of the grammaticalization phenomena discussed in section 4 can be viewed as "Euroversals", which represent areal commonalities rather than genetic ones. The role of language contact, both between languages within the branch itself and with languages from other families, is thus of major importance to the study of grammaticalization in the Germanic languages. Crucial features, such as heavy mutual borrowing of lexis or the decline of inflectional complexity, represent direct outcomes of intensive contact. However, contact is not equally important to all members of the branch. 
Unlike languages such as English or German, Faroese and Icelandic have remained largely in isolation, which has contributed to both greater retention of older grammatical features and a lesser ratio of borrowed lexis. Among the Germanic languages that have been shaped by contact situations, English stands out as a dramatic example, as it has been substantially influenced by Latin, Scandinavian, and French. On a larger scale, language contact is of further importance as many of the world's creole languages are Germanic-based.

4 Examples of grammaticalization in the Germanic languages

\subsection{Passive inflection}

In the North-Germanic languages, an inflectional passive (cf. Wiemer, this volume) has grammaticalized out of the Proto-Germanic reflexive pronoun *sik. On the formal side, the development is characterized by phonological reduction of the pronoun and simultaneous univerbation with the preceding verb. In present-day Faroese and Icelandic, the form of the suffix is $-s t$; in the languages of the mainland it has reduced further to $-s$.

$\begin{array}{lll}\text { Icelandic } & \begin{array}{l}\text { Urið } \\ \text { watch }\end{array} & \begin{array}{l}\text { tyndi-st } \\ \text { 'The watch got lost.' }\end{array} \\ \text { Swedish } & \begin{array}{l}\text { Ingenting } \\ \text { nothing hörde-s } \\ \text { 'Nothing could be heard.' }\end{array}\end{array}$

The semantic development of the pronoun first followed the cross-linguistically common path from reflexive to mediopassive. Analogous mediopassive constructions with sich, without univerbation, are found in German, but neither in Dutch nor in English. The Scandinavian mediopassive could express reflexivity (geymask 'hide oneself'), reciprocity (berjask 'fight one another'), anticausativity (andask 'die'), and passive (synjask 'be denied) at the same time (Heltoft 2006); passive is believed to be a late addition. In modern Scandinavian, the passive remains a productive pattern, whereas reflexivity is obligatorily expressed with a full reflexive pronoun and the other meanings are retained only in a number of reciprocal or deponent verbs (e.g. Swedish brottas 'wrestle', skämmas 'feel shame'). Besides the inflectional s-passive, the Scandinavian languages have grammaticalized a periphrastic passive, so that for instance Danish myrdes 'be murdered' is alternatively expressed as blive myrdet. Factors favouring the morphological variant include the absence of a concrete agent and the presence of a modal auxiliary, but the dynamics between competing passive constructions exhibit subtle crosslinguistic differences.

\subsection{Suffixed definite articles}

Another example from Scandinavian concerns definite articles (cf. DeMulder and Carlier, this volume). The North-Germanic languages express definiteness both with suffixed articles and, in the case of attributive constructions, with autonomous articles. As shown in (2), there are different forms for the two genders (utrum, neutrum), and adjectives inflect for definiteness. 
(2)

$\begin{array}{lll}\text { Swedish } & \begin{array}{l}\text { en bil } \\ \text { a car } \\ \text { 'a car' }\end{array} & \begin{array}{l}\text { bil-en } \\ \text { car-DEF } \\ \text { 'the car' }\end{array} \\ \text { Swedish } & \begin{array}{l}\text { ett hus } \\ \text { a house } \\ \text { 'a house' }\end{array} & \begin{array}{l}\text { hus-et } \\ \text { house-DEF } \\ \text { 'the house' }\end{array} \\ \text { Danish } & \begin{array}{l}\text { et hus } \\ \text { a house } \\ \text { 'a house' }\end{array} & \begin{array}{l}\text { hus-et } \\ \text { house-DEF } \\ \text { 'the house' }\end{array}\end{array}$

den fin-a bil-en

the large-DEF car-DEF

'the nice car'

det stor-a hus-et

the large-DEF house-DEF

'the large house'

det stor-e hus

the large-DEF house

'the large house'

The examples further show a difference between Danish and Swedish. Whereas Danish keeps the autonomous and the suffixed articles in complementary distribution, depending on the presence of an attributive adjective, Swedish allows their co-presence in what is called "double determination". Despite the vexing similarity of the indefinite autonomous article and the suffixed definite article, the origins of the latter are unclear (Dahl 2007: 34). Plausibly, a postposed demonstrative underwent univerbation with its head noun, but the putative source construction is neither preserved in the written record, nor is it retained in varietal usage.

\subsection{Auxiliaries in different functions}

All Germanic languages have grammaticalized a set of auxiliary verbs. These can be defined as verbal elements that have defective paradigms, cannot function as the main predicate of a clause, take verbal complements that are not fully finite, and carry grammatical meanings from domains such as tense, aspect, modality, and voice, amongst others.

The Germanic auxiliaries strongly represent the grammatical domain of modality (Krug, Ziegeler, this volume). Lexical verbs of ability, desire, and obligation have developed into auxiliaries with dynamic, deontic, epistemic, and interpersonal meanings. Functions of tense and aspect are also covered by auxiliaries. For instance, future time reference is conveyed by English will, Dutch zullen, Swedish ska, and German werden, but all of these have additional modal functions and are frequently viewed as core modal auxiliaries. Aspectual functions are found in perfect constructions and in cases of posture verb auxiliation, as is discussed below.

(3) Danish

Netvarket vil omfatte flere virksomheder.
network-DEF will include-INF several activities
'The network will comprise several activities.'

Dutch

Hij moet volgende week terugkomen. he must following week return.INF 'He has to return next week.'

Yiddish Keyner darf zikh keynmol nit ayln. no-one must self never not hurry.INF 'No-one should ever hurry.'

Besides auxiliaries that take bare infinitives as complements, several lexical verbs have come to be used with marked infinitival complements. These include verbs of movement, 
possession, and cognition, but also aspectualizers ('begin', 'continue', 'stop'), as well as the copula in certain collocations ('be about to').

(4) Swedish

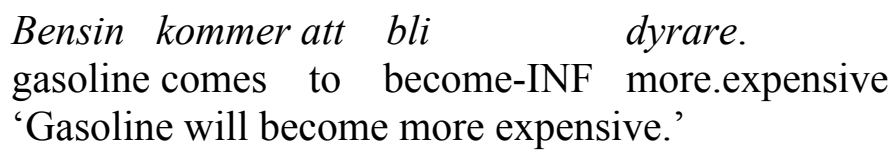

$\begin{array}{ll}\text { Icelandic } & \text { Ég kann að syngja. } \\ & \text { I know to sing.INF } \\ \text { 'I may sing.' }\end{array}$

Faroese Hann er um at fara.

he is about to go.INF

'He's about to go.'

A further functional domain of the Germanic auxiliaries is the passive. Here, lexical verbs of becoming (Swedish blive, German werden) or receiving (German bekommen, kriegen, English get), along with the copula, are complemented by a past participle.

$\begin{array}{lll}\text { Danish } & \begin{array}{l}\text { Huset } \\ \text { house-DEF blev }\end{array} & \text { solgt. } \\ \text { 'The house was sold.' } & \text { sell.PPART }\end{array}$

German Sie bekommt den Führerschein entzogen. she gets the driving.license revoke.PPART 'Her driving license is being revoked.'

English I was paid. / I got paid.

A European feature of the Germanic languages is the grammaticalization of a perfect auxiliary from a verb of possession, which is shared with Greek and the Romance languages, but with few languages elsewhere (Heine 1997). The constructions consist of a present tense form of a possession verb and a participle of a lexical verb, which can either be prefixed (Afrikaans), suffixed (Danish, English), or circumfixed (German).
Afrikaans
Sy het ge-werk.
Danish
Hun har arbejd-et.
German
Sie hat ge-arbeit-et.
English
She has work-ed.

The Germanic languages vary to the extent that the perfect alternates between a possession verb and the copula 'be' as an auxiliary. Forms such as English I have been correspond to Afrikaans $i k$ es gewees or German ich bin gewesen. Split auxiliary systems involving verbs meaning 'have' and 'be' have been suggested as a Euroversal (Heine and Kuteva 2006: 11).

Historically, the Germanic perfect constructions are thought to have been calqued from a corresponding Latin structure (Giacalone Ramat 2008). Latin habere grammaticalized into a perfect marker in the context of a resultative construction. The direct object of that construction was followed by a participle denoting the resultant state, thus roughly corresponding to an English sentence such as I have the book finished. The crucial step in the 
grammaticalization process was the reanalysis by which the participle was reinterpreted from a characteristic of the object ('I have the book, in a finished state') towards a completed action of the subject ('I just finished the book'). Despite its likely origin as a borrowed structure, the Germanic perfect constructions show developments that signal further grammaticalization, i.e. increases in frequency, loss of agreement on the participle, changes in placement of the participle, etc.

A current development of the European perfects is its ousting of the preterite in German, French, and Italian, especially in dialectal varieties (Heine and Kuteva 2006). As a corollary of its replacing the preterite, the German perfect has given rise to a reduplicated perfect construction of the kind shown in (7). It is however unclear whether this construction takes over the former function of the present perfect, functions as a pluperfect, or represents an autonomous renewal of a construction with past time reference.

$$
\text { German }
$$

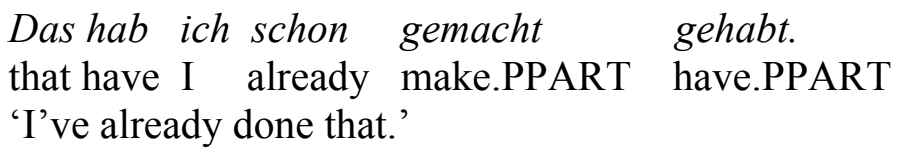

A special type of auxiliation can be observed in Dutch and the North-Germanic languages. Here, verbs of general posture ('sit', 'stand', 'lie') have come to express aspectual meanings, chiefly in the categories of durative or progressive aspect (Kuteva 1999; Lemmens 2005). The examples below illustrate constructions that have developed from lexical verbs meaning 'sit'.

$$
\begin{array}{ll}
\text { Dutch } & \begin{array}{l}
\text { Ze zit te studeren. } \\
\text { she sits to study.INF } \\
\text { 'She's studying'. }
\end{array} \\
\text { Faroese } & \begin{array}{l}
\text { Vi sótu og prátaðu. } \\
\text { we sat and chatted } \\
\text { 'We were chatting.' }
\end{array}
\end{array}
$$

The Dutch construction instantiates the common pattern of an auxiliary followed by a marked infinitive; the North-Germanic pattern involves a conjunction and is known as pseudocoordination. While in many cases the posture verb might be taken to literally indicate the posture that a human being assumes during a particular activity, this need not always be the case, as shown by the examples below.

(9) Dutch

Danish

\author{
Onze ploeg stond lamlendig te hockeyen. (Lemmens 2005: 185) \\ our team stood sluggishly to hockey \\ 'Our team was playing hockey sluggishly.'
}

Han ligger og kører rundt hele natten. (Braunmüller 1991: 103) he lies and drives around all night 'He has been driving all night long.'

Kuteva (1999) suggests that posture verbs become available as sources for grammaticalization once they are established as unmarked markers of location. In Dutch and the North-Germanic languages, verbs meaning 'sit' can be used to point out the location of an inanimate object. As a result of their wider applicability, posture verbs are thus thought to increase in frequency and undergo a process of semantic bleaching that facilitates their development into grammatical markers. 


\subsection{Discourse markers}

A common grammaticalization path in Germanic is the development of discourse markers out of conjunctions (cf. Onodera, Waltereit, this volume). Other typical sources are adverbs (really), imperatives (look), or prepositional phrases (in fact). Discourse markers can be defined as optional elements that are largely restricted to the spoken modality, and which are typically found in the periphery of turns (Auer and Günthner 2005). Their primary function lies in the organization of talk-in-interaction. Discourse markers may thus initiate a turn, indicate a topic change, or signal the beginning or continuation of a narrative, amongst several other functions. Examples of the development from conjunction to discourse marker include English although, because, and so. One example from Swedish is the coordinating conjunction men 'but', which has come to be used turn-initially, often in combination with $j a$ 'yes' or nej 'no', to signal emotional involvement of the speaker.

$$
\begin{aligned}
& \text { Swedish jag har hört din röst men jag har inte sett dej } \\
& \text { I have heard your voice but I have not seen you } \\
& \text { 'I have heard your voice but I haven't seen you.' }
\end{aligned}
$$

Swedish

$$
\begin{aligned}
& \text { nej men god dag god dag Kalle } \\
& \text { no but good day good day Kalle }
\end{aligned}
$$

'Well hello hello Kalle!'

A German example is the subordinating concessive conjunction obwohl 'although', which has acquired a corrective function as a discourse marker. In the dialogue below, speaker B first makes a statement, then pauses and takes it back with an utterance preceded by obwohl (example from Günthner 1999).

\section{(11) German}

Sie kommt heute, obwohl sie krank ist. she comes today, although she sick is 'She will come here today, although she is sick.'

\section{German A: brauchst du noch en Kissen? need you still a pillow 'Do you need another pillow?'}
B: hm ne das reicht (pause) obwohl des isch doch unbequem hm no this suffices although this is still uncomfortable 'Hm, no, it's okay. $\quad$ No, it's still uncomfortable.'

In examples such as these, conjunctions come to be used outside of their typical syntactic context, thus undergoing decategorialization, which also shows itself in the development of independent intonation, strong restrictions on the initial or final position, and a replacement of earlier grammatical meanings with discourse-pragmatic functions.

\subsection{Germanic examples of degrammaticalization}

Surveys of putative counterexamples to the unidirectionality of grammaticalization (Janda 2001, Norde, this volume) typically include several prominent examples from the Germanic languages. These include the formation of lexical verbs from prepositions (to down a drink) or 
the development of the $s$-genitive in English and North-Germanic from a case marker to a clitic (Rosenbach 2004, Norde 2006). This section briefly reviews two examples of degrammaticalization that have been proposed.

Burridge (1998) reports the case of wotte 'wish' from Pennsylvania German (also known as Pennsylvania Dutch), which is a lexical verb that appears to derive from a modal auxiliary welle 'want to'. The latter shows multiple signs of advanced grammaticalization, such as the preference for non-finite verbal complements and the inability to form the passive. The form wotte goes back to the past subjunctive of that modal (wette), which has become rounded. Unlike its source, it is unable to take infinitival complements. It does however occur with sentential complements. The verb conveys a fully lexical meaning that can be modified adverbally. These examples appear to reverse processes that the modal welle underwent in its grammaticalization.

\author{
PA German *Ich wott kumme. \\ I want come-INF \\ 'I want to come.' \\ PA German Ich wott, du kennscht frieher kumme. \\ I wish you could earlier come \\ 'I wish you could come sooner.' \\ PA German Wott mal hart fer sell. \\ wish MP hard for that \\ 'Wish hard for that.'
}

Burridge suggests a socio-cultural explanation for the apparent developmental U-turn of wotte. The Mennonite lifestyle that is maintained by the speakers of Pennsylvania German greatly values modesty, so that there was a functional need for a marker of a detached, uninvolved marker of preference. The preterite form of a grammatical marker then offered the right characteristics to be coopted for such a purpose.

Another putative counterexample from the domain of modality has been brought up by van der Auwera (2002) with the case of the Swedish auxiliary ma 'may, be permitted'. The argument is that må as a modal auxiliary has given rise to a lexical verb meaning 'feel'.

$\begin{array}{ll}\text { Swedish } & \begin{array}{l}\text { Du må säga vad du vill, han } \\ \text { you may say what you want he } \\ \text { 'You can say whatever you want, }\end{array} \\ \text { Swedish } & \begin{array}{l}\text { Hunden mår inte bra. } \\ \text { dog-DEF feel-PRS not good } \\ \text { 'The dog does not feel well.' }\end{array}\end{array}$

Andersson (2008) challenges this interpretation by showing that the lexical meaning is in fact already attested in the earliest written sources in Swedish, and that corresponding examples exist in Old Norse, Old English, and Old High German. As an alternative to the degrammaticalization scenario, Andersson proposes that both the modal and the lexical verb originate from a Proto-Germanic verb with the meaning 'be strong, have power'. Such a meaning allows conceptual extension to modal meanings of possibility and permission, as well as to a lexical meaning of psychological constitution. 
References

Andersson, Peter. 2008. Swedish $m a ̊$ and the (de)grammaticalization debate. In Elena Seoane and María José López-Couso (eds.), Theoretical and Empirical Issues in Grammaticalization. Amsterdam: Benjamins, 15-32.

Auer, Peter and Susanne Günthner. 2005. Die Entstehung von Diskursmarkern im Deutschen - ein Fall von Grammatikalisierung?. In Torsten Leuschner and Tanja Mortelsmans, (eds.), Grammatikalisierung im Deutschen. Berlin: de Gruyter, 335-362.

Braunmüller, Kurt. 1991. Die skandinavischen Sprachen im Überblick. Tübingen: Francke.

Burridge, Kate. 1998. From modal auxiliary to lexical verb: The curious case of Pennsylvania German wotte. In Richard M. Hogg, and Linda Bergen eds. Historical Linguistics 1995. Selected Papers from the 12th ICHL, Vol. 2. Germanic Linguistics. Amsterdam: Benjamins, 19-31.

Culicover, Peter. 2008. The rise and fall of constructions and the history of English $d o-$ Support. Journal of Germanic Linguistics 20, 1-52.

Dahl, Östen. 2007. Grammaticalization in the North: Noun Phrase Morphosyntax in Scandinavian Vernaculars. Preliminary version, University of Stockholm.

Giacalone-Ramat, Anna. 2008. Areal convergence in grammaticalization processes. In Maria José López-Couso and Elena Seoane (eds.) 2008. Rethinking Grammaticalization. Amsterdam: Benjamins?, 129-167.

Günthner, Susanne. 1999. Entwickelt sich der Konzessivkonnektor obwohl zum Diskursmarker? Grammatikalisierungstendenzen im gesprochenen Deutsch. Linguistische Berichte 180: 409-46.

Heine, Bernd. 1997. Possession: Sources, Forces, and Grammaticalization. Cambridge: Cambridge University Press.

Heine, Bernd and Tania Kuteva. 2006. The Changing Languages of Europe. Oxford: Oxford University Press.

Heltoft, Lars. 2006. Grammaticalisation as content reanalysis: The modal character of the Danish S-passive. In O.N. Thomsen (ed.), Competing Models of Linguistic Change. Evolution and Beyond. Amsterdam: John Benjamins, 268-288.

Henriksen, Carol and Johan van der Auwera. 1994. The Germanic languages. In Ekkehard König and Johan van der Auwera (eds.), The Germanic languages. London: Routledge, $1-18$.

Janda, Richard D. 2001. Beyond "pathways" and "unidirectionality": On the discontinuity of transmission and the counterability of grammaticalization. Language Sciences 23, 2-3: 265-340.

Kortmann, Bernd. 1997. Adverbial Subordination: a Typology and History of Adverbial Subordinators. Berlin: Mouton de Gruyter.

Kuteva, Tania A. 1999. On 'sit'/'stand'/'lie' auxiliation. Linguistics 32, 2: 191-213.

Lemmens 2005 MISSING

Norde, Muriel. 2006. Demarcating degrammaticalization: the Swedish s-genitive revisited. Nordic Journal of Linguistics 29, 2: 201-38.

Ringe, Don. 2006. From Proto-Indo-European to Proto-Germanic. Oxford: Oxford University Press. 
Rosenbach, Annette. 2004. The English s-genitive - a case of degrammaticalization? In Olga Fischer, Muriel Norde, and Harry Perridon (eds.). Up and Down the Cline - the Nature of Grammaticalization. Amsterdam: John Benjamins, 73-96.

Thràinsson, Höskuldur. 1994. Icelandic. In Ekkehard König and Johan van der Auwera (eds.), The Germanic languages. London: Routledge, 1-18.

van der Auwera, Johan. 2002. More thoughts on degrammaticalization. In Ilse Wischer and Gabriele Diewald (eds.), New Reflections on Grammaticalization. Amsterdam: John Benjamins, 19-29. 